\title{
IDENTIFIKASI JENIS BUBUK KOPI MENGGUNAKAN ELECTRONIC NOSE DENGAN METODE PEMBELAJARAN BACKPROPAGATION
}

\author{
Desti Rabersyah $^{1 *}$, Firdaus ${ }^{2}$, Derisma ${ }^{3}$ \\ ${ }^{1,3}$ Sistem Komputer Fakultas Teknologi Informasi Universitas Andalas \\ ${ }^{2}$ Teknik Elektro Politeknik Negeri Padang \\ *Corresponding author, e-mail: derisma@fti.unand.ac.id
}

\begin{abstract}
Abstrak - Perkembangan teknologi memungkinkan penciptaan sebuah sistem dengan cara kerja menyerupai hidung, yaitu electronic nose (e-nose). E-nose dapat dimanfaatkan dalam berbagai bidang aplikasi, salah satunya untuk membedakan jenis kopi. Terdapat dua jenis utama kopi, yaitu kopi arabika (Coffea Arabica) dan kopi robusta (Coffea Robusta). Kopi memiliki karakteristik yang berbeda dan unik untuk masing - masing jenisnya. Karakteristik kopi dapat ditentukan berdasarkan kandungan gas pada kopi menggunakan e-nose. Perangkat ini terdiri dari 5 unit sensor gas yaitu TGS 2610, TGS 2611, TGS 2602, TGS 2620 dan TGS 822. Pola data diperoleh dari perubahan resistansi masing - masing sensor apabila mendeteksi aroma kopi yang mengakibatkan perubahan tegangan. Pola data tersebut akan diolah menggunakan jaringan saraf tiruan (JST) backpropagation. Arsitektur JST backpropagation yang digunakan dibentuk dari 5 node input, 6 node hidden dan 2 node output. Hasil output JST backpropagation yang diharapkan dapat membedakan kopi arabika dan robusta serta mampu mengenali keadaan udara bebas (tanpa kopi). Hasil pengujian memperlihatkan JST backpropagation mampu melakukan identifikasi dengan tingkat keberhasilan $40 \%$ untuk arabika, $100 \%$ untuk robusta dan $100 \%$ untuk udara bebas (tanpa kopi).
\end{abstract}

\section{Kata Kunci : Electronic Nose, Jaringan saraf tiruan, JST backpropagation}

\begin{abstract}
The development of technology allows the creation of a system in a manner resembling a nose job, the electronic nose (e-nose). E-nose can be utilized in various application fields, one of which is to distinguish the type of coffee. There are two main types of coffee, Arabica (Coffea arabica) and robusta (Coffea Robusta). Coffee has different characteristics and unique for its kind. Characteristics of coffee can be determined based on the gas content of coffee using e-nose. This device consists of 5 units of gas sensors that TGS 2610, TGS 2611, TGS 2602, TGS and TGS 2620 822. The pattern of data obtained from the respective resistance change, if the sensors detect coffee that resulted in a change in voltage. Pattern data will be processed using backpropagation neural network. Backpropagation architecture used is formed from the 5 input nodes, 6 hidden nodes and 2 output nodes. The result are expected to distinguish between arabica and robusta and be able to recognize the state of free air (without coffee). The test showed backpropagation NN able to identify with a success rate of $40 \%$ for arabica, robusta and $100 \%$ to $100 \%$ for free air (without coffee).
\end{abstract}

Keywords : Electronic nose, Neural Network, Backpropagation

Copyright $(2) 2016$ JNTE. All rights reserved

\section{PENDAHULUAN}

Hidung merupakan indera yang merespon terhadap rangsangan berupa bau. Hidung mampu mendeteksi, mengenal dan juga membedakan berbagai macam bau. Perkembangan teknologi memungkinkan penciptaan sebuah sistem dengan cara kerja menyerupai hidung, yaitu electronic nose (enose). E-nose dapat dimanfaatkan dalam berbagai bidang aplikasi, diantaranya untuk mengukur dan menentukan kualitas makanan, memonitor pencemaran udara, serta pendeteksian berbagai macam gas dan racun. Di dalam aplikasi industri makanan dan minuman e-nose telah digunakan pada berbagai macam 
jenis makanan dan minuman, seperti; daging, biji-bijian, bir, jamur, keju, gula, ikan, buahbuahan, jus, minuman berakhohol dan kopi [1].

Kopi (Coffea sp.) adalah spesies tanaman yang termasuk dalam famili Rubiaceae dan genus Coffea. Tanaman kopi terdiri dari jenis Coffea robusta, Coffea arabica, dan Coffea liberica. Kopi merupakan komoditas ekspor dunia dengan nilai ekonomis yang relatif tinggi di pasaran, di Indonesia kopi juga merupakan salah satu komoditas ekspor unggulan yang terus dikembangkan[2][3].

Pada penelitian ini, akan dikembangkan sebuah sistem Identifikasi Jenis Bubuk Kopi Menggunakan Electronic Nose dengan Metode Pembelajaran JST Backpropagation sebagai model dari hidung manusia yang merepresentasikan aplikasi yang mampu mengidentifikasi jenis bubuk kopi.

\section{TINJAUAN PUSTAKA}

\subsection{Kopi}

Tumbuhan kopi diperkirakan berasal dari hutan-hutan tropis di kawasan Afrika. Kopi arabika berasal dari kawasan pegunungan tinggi di Barat Ethiopia maupun di kawasan utara Kenya, kopi Robusta di Ivory Coast dan Republik Afrika Tengah. Hal ini membuktikan bahwa tumbuhan kopi mudah beradaptasi dengan lingkungan tumbuhnya[4].

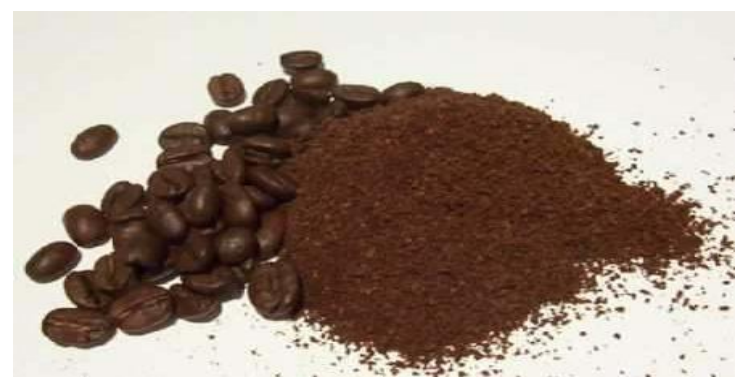

Gambar 1. Biji Dan Bubuk Kopi

Dari sekian banyak jenis biji kopi yang dijual di pasaran, hanya terdapat dua jenis spesis utama, yaitu kopi arabika (Coffea Arabica) dan Robusta (Coffea Robusta). Masing-masing jenis kopi ini memiliki keunikannya masing-masing. Adapun komposisi kimia dari biji kopi sebelum dan setelah disangrai dapat dilihat pada Tabel 1 berikut ini [5]:
Tabel 1. Komposisi Kimia Biji dan Bubuk Kopi

\begin{tabular}{|l|l|l|l|l|}
\hline \multirow{2}{*}{ Komponen } & \multicolumn{2}{|c|}{ Kopi Arabika } & \multicolumn{2}{c|}{ Kopi Robust a } \\
\cline { 2 - 5 } & \multicolumn{1}{|c|}{ Biji (\%) } & $\begin{array}{c}\text { Roasted } \\
\text { (\%) }\end{array}$ & Biji (\%) & $\begin{array}{c}\text { Roasted } \\
\text { (\%) }\end{array}$ \\
\hline Minera1 & $3,0-4,2$ & $3,5-4,5$ & $4,0-4,5$ & $4,6-5,0$ \\
\hline Ka feim & $0,9-1,2$ & 1,0 & $1,6-2,4$ & 2,0 \\
\hline Polisakarida & $50,0-55,0$ & $24,0-39,0$ & $37,0-47,0$ & - \\
\hline Lipid & $12,0-18,0$ & $14,5-20,0$ & $9,0-13,0$ & $11,0-16,0$ \\
\hline $\begin{array}{l}\text { Asam } \\
\text { Klorogenat }\end{array}$ & $5,5-8,0$ & $1,2-2,3$ & $7,0-10,0$ & $3,9-4,6$ \\
\hline $\begin{array}{l}\text { Asam } \\
\text { Ammo }\end{array}$ & 2,0 & 0,0 & 2,0 & 0,0 \\
\hline Protein & $11,0-13,0$ & $13,0-15,0$ & $11,0-13,0$ & $13,0-15,0$ \\
\hline $\begin{array}{l}\text { Asam } \\
\text { Humm }\end{array}$ & - & $16,0-17,0$ & $16,0-17,0$ & 15,02 \\
\hline
\end{tabular}

\subsection{Sensor Gas}

Sensor gas adalah alat yang dapat menghasilkan sinyal listrik sebagai fungsi interaksinya dengan senyawa kimia, seperti gas atau uap senyawa organik. Bahan detektor gas dari sensor gas semikonduktor adalah metal oksida, khususnya senyawa $\mathrm{SnO} 2$ [6].

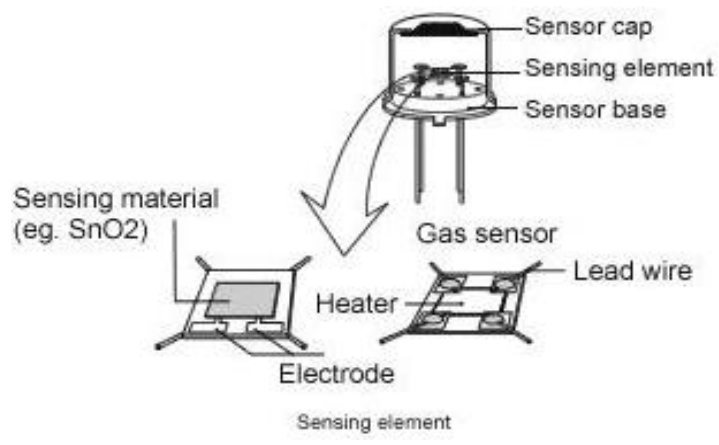

Gambar 2. Struktur Sensor Gas

\section{Sensor TGS 2610}

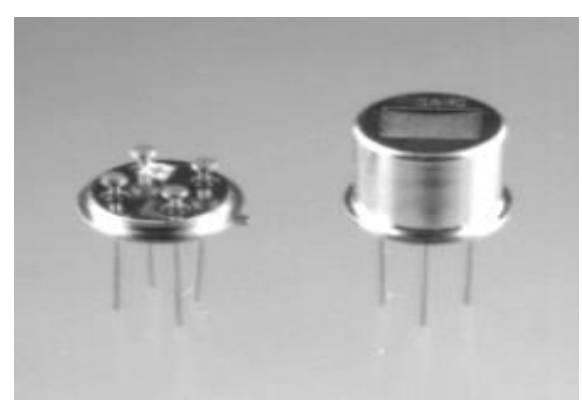

\section{Gambar 3. TGS 2610}

TGS 2610 adalah suatu jenis semikonduktor oksida logam film tebal yang dapat mendeteksi adanya kebocoran gas LPG, beroperasi dengan konsumsi arus yang rendah dan memiliki daya tahan yang lama dalam penggunaannya. 


\section{Sensor TGS 2611}

Sensor gas TGS 2611 adalah sensor gas yang memiliki sensitifitas tinggi terhadap adanya konsentrasi gas metana disekitar sensor tersebut. Sensor gas TGS2611 memiliki konsumsi arus yang rendah sehinga dapat digunakan dalam waktu yang lama. TGS 2611 membutuhkan $56 \mathrm{~mA}$ untuk konsumsi arus.

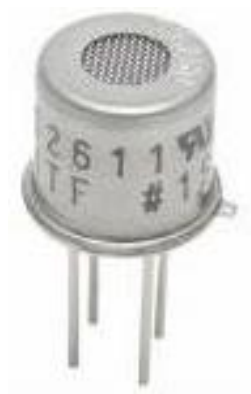

Gambar 4. TGS 2611

\section{Sensor TGS 2602}

Sensor TGS 2602 memiliki tingkat sensitivitas yang baik terhadap konsentrasi kecil zat berbau seperti amonia dan H2S ynag dihasilkan dari material buangan pada lingkungan kantor atau rumah. TGS 2602 juga memiliki sensitivitas yang tinggi terhadap konsentrasi kecil VOCs seperti toluena yang dipancarkan dari proses penghalusan kayu dan produk konstruksi.

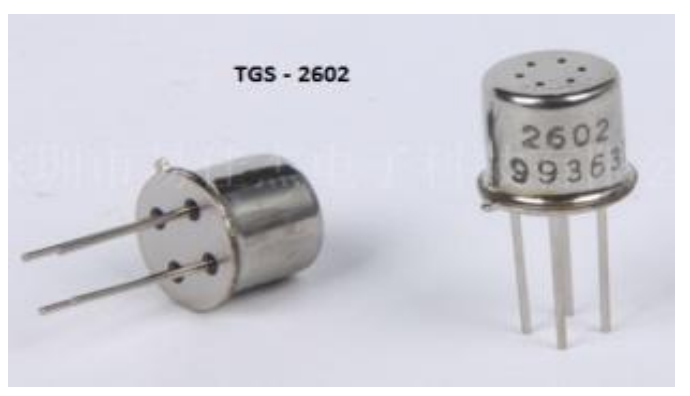

Gambar 5. TGS 2602

\section{Sensor TGS 2620}

Sensor TGS 2620 memiliki sensitivitas yang tinggi terhadap uap larutan organik dan uap lainya. Selain itu TGS 2620 juga sensitif pada gas yang mudah terbakar seperti karbon monoksida. Sehingga TGS 2620 sangat baik dijadikan sebagai general purpose gas sensor.

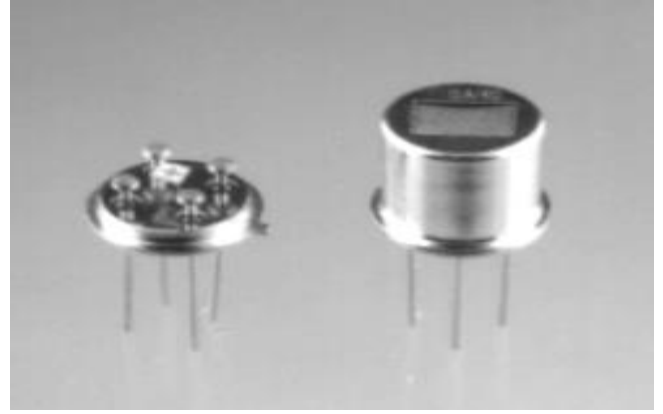

Gambar 6. TGS 2620

\section{Sensor TGS 822}

TGS 822 memiliki sensitivitas yang tinggi terhadap uap pelarut organik dan uap lainya. TGS 822 juga memiliki kepekaan terhadap berbagai gas yang mudah terbakar seperti karbon monoksida.

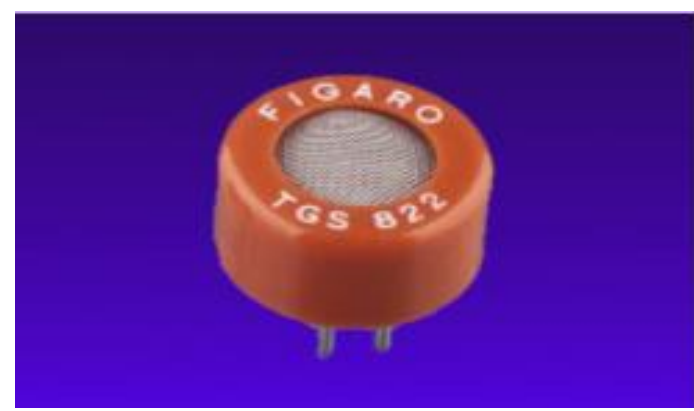

Gambar 7. TGS 822

\subsection{Electronic Nose}

E-nose memiliki serangkaian sensor gas yang masing-masing akan memberikan reaksi terhadap perubahan bau atau aroma. Aroma atau odor akan memberikan reaksi berupa perubahan tahanan pada setiap gas sensor. Dengan adanya perubahan tahanan dari setiap gas sensor ini akan mengakibatkan timbulnya perubahan voltase. Data yang diperoleh dari perubahan voltase ini berupa data digital komputer. Untuk selanjutnya, data tersebut akan diolah dengan menggunakan metode neural network[7].

Prinsip kerja e-nose menirukan fungsi hidung manusia, yang mana di dalamnya dijumpai berbagai reseptor pengidentifikasi aroma. Reseptor - reseptor ini fungsinya digantikan oleh sensor pada e-nose, tiap reseptor yang ada akan memberikan respon yang berbeda dari uap aroma yang sama[1]. 


\subsection{Jaringan Syaraf Tiruan Backpropagation}

Jaringan syaraf tiruan (JST) adalah sistem pemroses informasi yang memiliki karakteristik mirip dengan jaringan syaraf biologi.Backpropagation melatih jaringan untuk mendapatkan keseimbangan antara kemampuan jaringan untuk mengenali pola yang digunakan selama pelatihan, serta kemampuan jaringan untuk memberikan respon yang benar terhadap pola masukan yang serupa (tapi tidak sama) dengan pola yang dipakai selama pelatihan. Backpropagation memiliki lapisan input, lapisan output dan beberapa lapisan tersembunyi yang maing - masing terdiri dari beberapa unit[8].

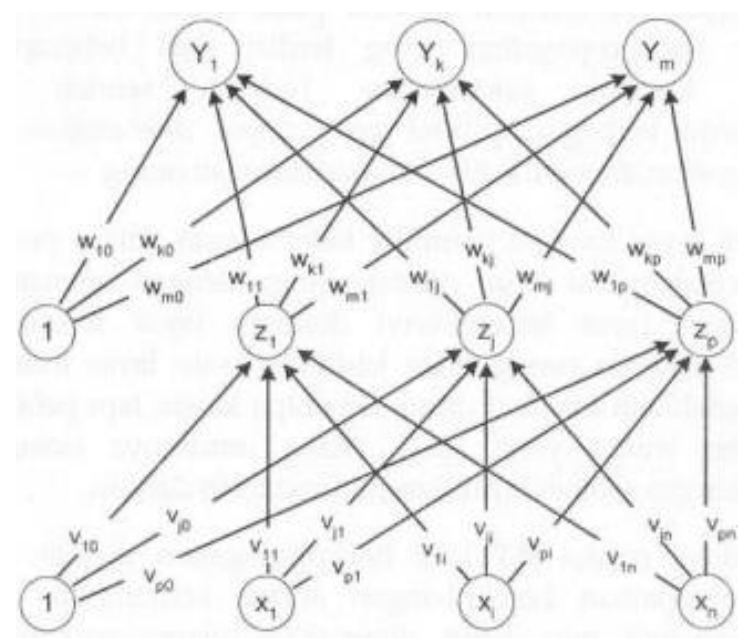

Gambar 8. Arsitektur JST Backpropagation[6]

Pelatihan backpropagation meliputi 3 fase. Fase pertama adalah fase maju. Pola masukan menggunakan fungsi aktivasi yang ditentukan. Fase kedua adalah fase mundur. Selisih antara keluaran jaringan dengan target yang diinginkan merupakan kesalahan yang terjadi. Kesalahan tersebut dipropagasi mundur, dimulai dari garis yang berhubungan langsung dengan unit-unit di lapisan keluaran. Fase ketiga adalah modifikasi bobot untuk menurunkan kesalahan yang terjadi. Setelah pelatihan selesai dilakukan, jaringan dapat dipakai untuk pengenalan pola[8].

\section{METODOLOGI}

Sistem yang akan dibangun pada penelitian ini akan menggunakan beberapa set sensor, arduino dan PC, seperti Gambar 9.

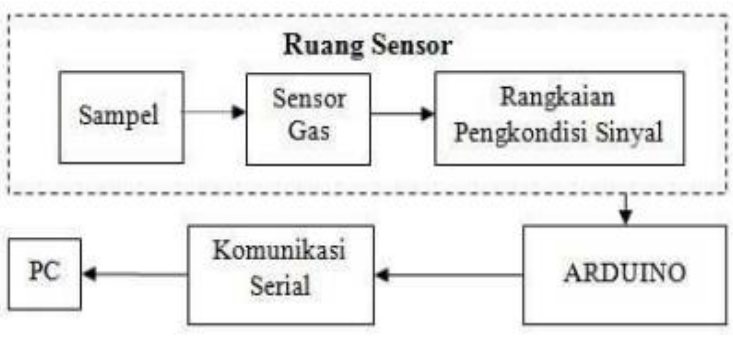

Gambar 9. Rancangan Sistem

Sitem akan menerima input sinyal dari beberapa set sensor gas, yaitu; TGS 2610, TGS 2611, TGS 2602, TGS 2620, dan TGS 822. Ketika sensor mendeteksi adanya unsur gas dari aroma bubuk kopi maka resistansi dari sensor akan berubah sehingga mengakibatkan perubahan voltase. Resistansi sensor akan menurun tergantung konsentrasi zat yang terdeteksi, semakin kuat konsentrasi zat yang terdeteksi maka semakin rendah resistansi sensor. Sinyal ini akan diproses oleh rangkaian pengkondisi sinyal untuk diteruskan ke rangkaian analog digital converter (ADC) untuk dikonversi ke dalam bentuk digital. Sinyal dalam bentuk digital inilah yang akan diteruskan ke PC untuk diolah menggunakan JST backpropagation.

JST Backpropagation yang akan digunakan dibangun dengan arsitektur 1 input layer 5 node, 1 hidden layer 6 node, dan 1 output layer 2 node, seperti yang dapat dilihat pada Gambar 10.

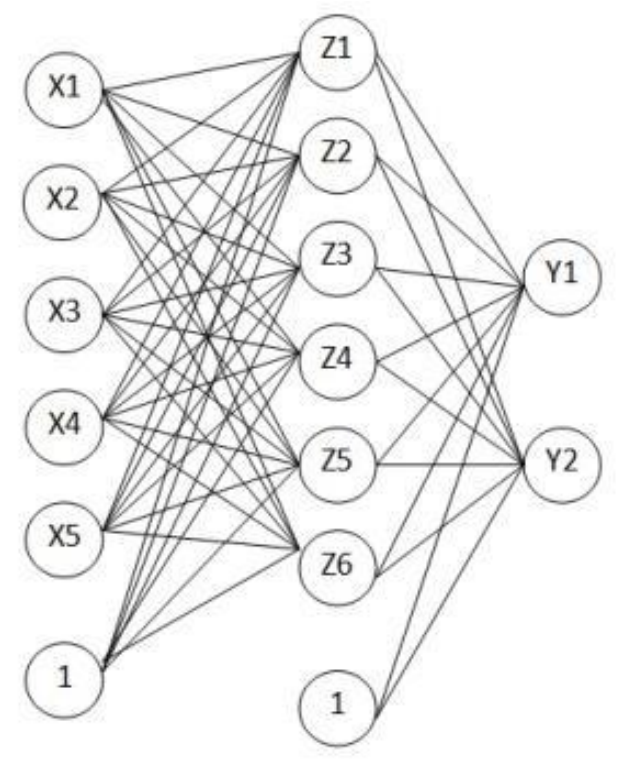

Gambar 10. Rancangan Struktur JST Backpropagation 
Pengolahan data akan dilakukan dengan melakukan pelatihan JST backpropagation dan identifikasi forward-propagation. Proses pelatihan dapat dilihat pada Gambar 11.

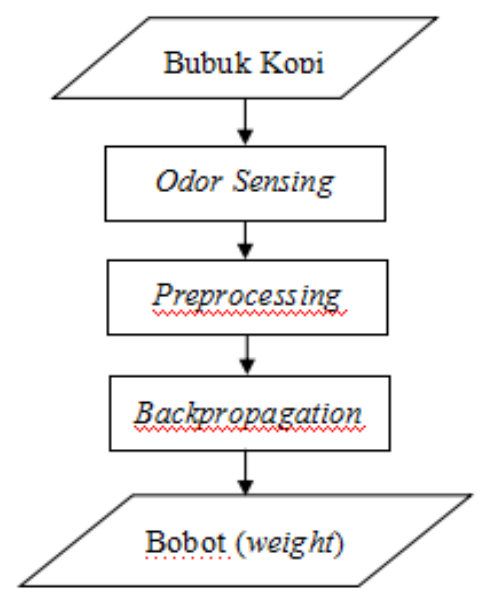

Gambar 11. Rancangan Proses Training Backpropagation

Setelah proses training diatas terpenuhi maka nilai bobot telah diperoleh untuk masingmasing sampel, selanjutnya proses identifikasi telah dapat dilakukan. Proses ini hampir sama dengan proses pembelajaran, hanya saja pada proses identifikasi tidak ditujukan untuk memperoleh bobot karena sistem telah memiliki nilai bobot hasil dari proses pembelajaran. Proses pengidentifikasian yang dapat dilihat pada Gambar 12.

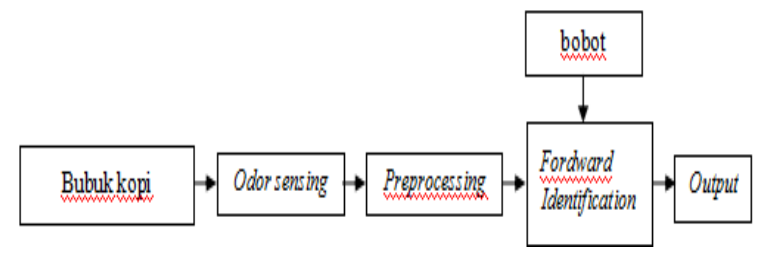

Gambar 12. Proses Identifikasi

Berikutnya akan diperoleh hasil keputusan dari data input yang dideteksi oleh sensor gas setelah diproses menggunakan metode JST Backpropagation. Hasil yang diharapkan adalah mampu membedakan dan mengidentifikasi bubuk kopi berdasarkan jenisnya masing-masing.

\section{HASIL DAN PEMBAHASAN}

Gambar 13 menampilkan Implementasi dari E-Nose. Selanjutnya pengujian dilakukan untuk mengetahui bahwa sistem yang dibuat dapat berjalan dengan baik dan stabil.

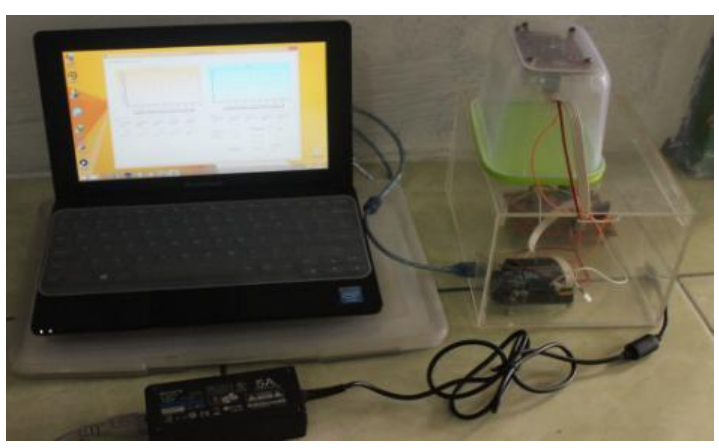

Gambar 13. Implementasi Sistem

\subsection{Pengujian Respon Sensor}

Pengukuran respon sensor gas dilakukan terhadap tiga macam sampel data, yaitu sampel udara bebas (tanpa kopi), sampel kopi arabika, sampel kopi robusta. Sebelum melakukan pengujian, sensor dipanaskan selama \pm 20 menit hingga nilai tegangan pada grafik terlihat stabil. Pengujian dilakukan dengan mengisolasi sampel kopi di dalam wadah uji yang berhubungan langsung dengan sederetan sensor gas. Rangkaian ini akan mengirim data ke Arduino untuk selanjutnya akan dikirimkan ke PC menggunakan kabel USB Arduino. Respon sensor akan terlihat pada perubahan garfik program yang ditampilkan pada PC/laptop. Data yang digunakan adalah data pada counter ke-400.

Adapun respon sensor terhadap masing masing sampel adalah sebagai berikut:

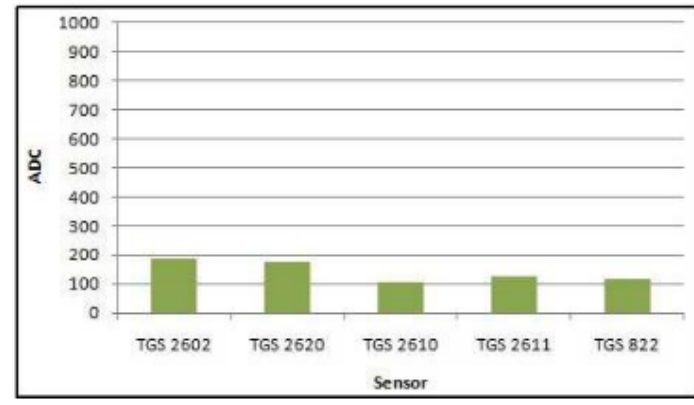

Gambar 14. Respon Sensor Tanpa Kopi

Percobaan pertama dilakukan terhadap sampel tanpa kopi. Gambar 14 memperlihatkan pola data pada kondisi udara bebas (tanpa kopi). Data ini akan menjadi acuan untuk kedua jenis sampel kopi. 


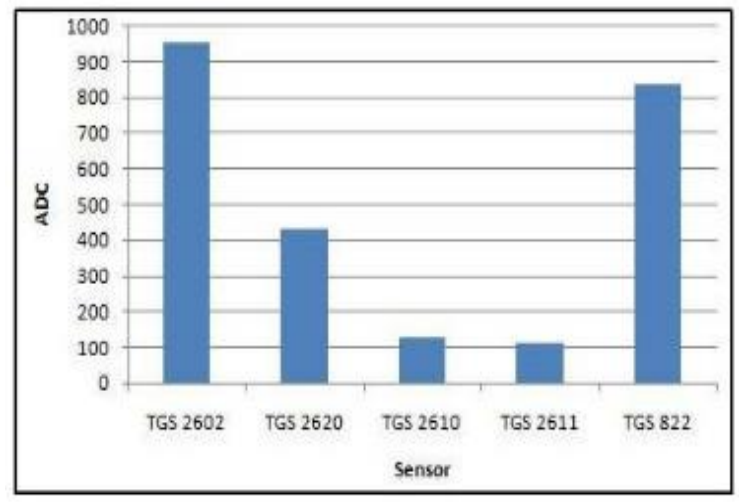

Gambar 15. Respon Sensor Kopi Arabika

Percobaan kedua dilakukan terhadap sampel kopi arabika. Berdasarkan gambar 15 terlihat terjadinya peningkatan nilai ADC pada sensor TGS 2602, TGS 2620 dan TGS 822. Hal ini mengindikasikan terdeteksinya kandungan hidrogen sulfida, alkhohol serta karbonmonoksida pada sampel kopi arabika.

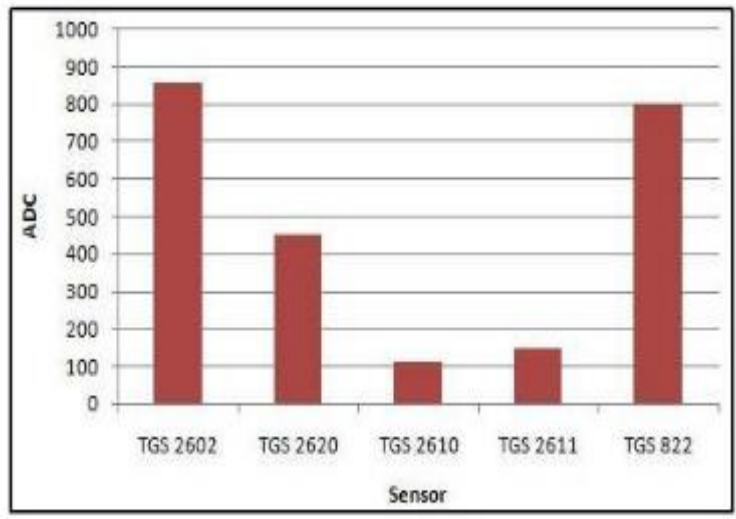

Gambar 16. Respon Sensor Kopi Robusta

Percobaan ketiga dilakukan terhadap sampel kopi robusta. Berdasarkan gambar 16 juga terlihat terjadinya peningkatan nilai ADC pada sensor TGS 2602, TGS 2620 dan TGS 822. Hal ini mengindikasikan pada kopi robusta juga dideteksi kandungan hidrogen sulfida, alkhohol serta karbonmonoksida.

\subsection{Pengujian Sistem}

\subsubsection{Training Backpropagation}

Proses training akan dilakukan terhadap data yang telah diperoleh sebelumnya. Proses training ini menggunakan metode JST backpropagation dengan fungsi aktivasi sigmoid binner, oleh karena itu data yang diperoleh harus ditranformasikan terlebih dahulu ke interval keluaran fungsi aktivasi sigmoid binner, dengan menggunakan metode normalisasi data sebagai berikut:

$$
x^{\prime}=\frac{0.8(x-a)}{b-a}+0.1
$$

Keterangan :

$\mathrm{x}=$ nilai $\mathrm{ADC}$

$\mathrm{x}^{\prime}=$ nilai setelah transformasi

$\mathrm{a}=$ data minimum

$\mathrm{b}=$ data maksimum

Proses training dilakukan dengan menggunakan MATLAB untuk menghasilkan nilai bobot baru yang akan digunakan dalam proses identifikasi. Pada proses training, nilai mean square error (MSE) yang digunakan adalah 0,0001 dan laju pemahaman $(\alpha)$ sebesar 0,1 .

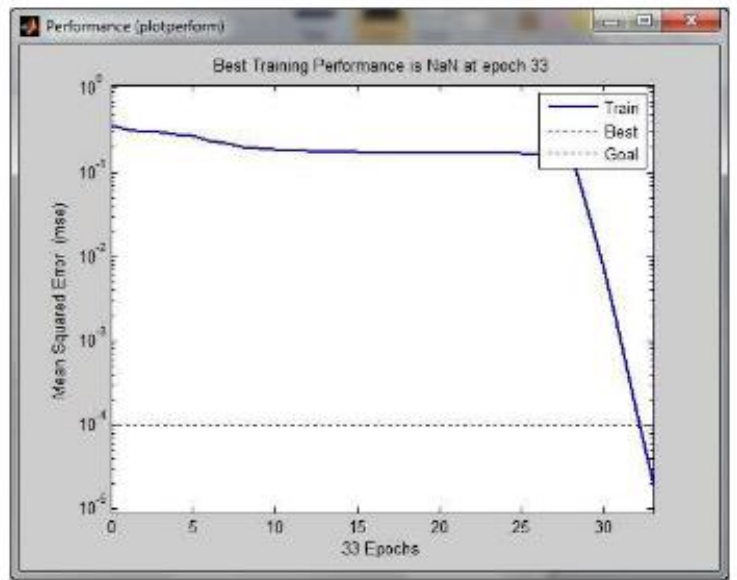

Gambar 17. Performance Proses Training

Gambar 17 memperlihatkan proses training dimana batas nilai MSE $=0.0001$ telah dilewati pada epoch ke-33. Berdasarkan gambar 17 proses training telah berhasil dilakukan dan mencapai target yang telah ditetapkan.

\subsubsection{Identifikasi Data Sampel Uji}

Proses identifikasi akan dilakukan sebanyak 10 kali percobaan untuk masing masing sampel. Pada tahap identifikasi akan digunakan proses forward identification. Hasil identifikasi dapat ditampilkan pada layar monitor PC/Laptop.

Setelah melakukan pengujian terhadap sampel uji, maka didapatkan data hasil pengujian sebagai berikut : 
Tabel 2. Hasil Identifikasi Sampel Uji

\begin{tabular}{|c|c|c|c|c|c|c|c|c|c|c|c|}
\hline \multicolumn{12}{|c|}{ TANPA KOPI } \\
\hline Percobaanke- & 1 & 2 & 3 & 4 & 5 & 6 & 7 & 8 & 9 & 10 & \multirow{2}{*}{$100 \%$} \\
\hline Hasil & $\sqrt{ }$ & $\sqrt{ }$ & $\mathrm{v}$ & $\sqrt{v}$ & $\sqrt{ }$ & $\sqrt{1}$ & v & $\sqrt{v}$ & $\sqrt{ }$ & $\sqrt{ }$ & \\
\hline \multicolumn{12}{|c|}{ ARABIKA } \\
\hline Percobaanke- & 1 & 2 & 3 & 4 & 5 & 6 & 7 & 8 & 9 & 10 & \multirow{2}{*}{$40 \%$} \\
\hline Hasil & $\mathrm{x}$ & $\mathrm{x}$ & $\mathrm{v}$ & $\mathrm{x}$ & $v$ & $v$ & $\mathrm{x}$ & $v$ & $\mathrm{x}$ & $\mathrm{x}$ & \\
\hline & & \multicolumn{4}{|c|}{ ROBUSTA } & & & & & & \\
\hline Percobaanke- & 1 & 2 & 3 & 4 & 5 & 6 & 7 & 8 & 9 & 10 & \multirow{2}{*}{$100 \%$} \\
\hline Hasil & $\mathrm{v}$ & $v$ & $\mathrm{v}$ & $\mathrm{v}$ & $v$ & $\mathrm{v}$ & $v$ & $v$ & $\mathrm{v}$ & $v$ & \\
\hline
\end{tabular}

\section{KESIMPULAN}

Setelah dilakukan beberapa kali pengujian dan menganalisa hasil yang diperoleh maka dapat diambil kesimpulan bahwa:

1. Dengan mengimplementasikan jaringan saraf tiruan backpropagation sistem mampu melakukan identifikasi jenis bubuk kopi dengan tingkat keberhasilan untuk udara netral (tanpa kopi), kopi arabika dan kopi robusta secara berturut-turut adalah $100 \%, 40 \%$ dan $100 \%$.

2. Sensor gas TGS 2602, TGS 2620 dan TGS 822 mendeteksi adanya kandungan gas amonia, hidrogen sulfida, alkhohol dan karbon monoksida pada bubuk kopi sedangkan sensor gas TGS 2610 dan TGS 2611 tidak mendeteksi adanya kandungan gas butana dan metana pada bubuk kopi.

3. Kandungan gas amonia, hidrogen sulfida dan karbonmonoksida pada bubuk kopi arabika lebih tinggi dibandingkan bubuk kopi robusta sedangkan kandungan alkhohol pada bubuk kopi arabika lebih rendah dibandingkan bubuk kopi robusta.

\section{DAFTAR PUSTAKA}

[1] Hendrick. Rivai, Muhammad. Tasripan. 2010. Klasifikasi Odor Pada Ruang Terbuka dengan Menggunakan Short Time Fourier Transform dan Neural Learning Vector Quantization. Digilib ITS, Surabaya.

[2] Najiyati, S. Danarti, 1997. Budidaya Kopi dan Pengolahan Pasca Panen. Penebar Swadaya, Jakarta.
[3] Spillane, J.J. 1990. Komoditi Kopi Peranannya Dalam Perekonomian Indonesia. Kanisius, Yogyakarta.

[4] Siswoputranto, P.S., 1992. Kopi Internasional dan Indonesia. Kanisius, Yogyakarta.

[5] Clarke, R.J., R.Macrae. 1985. Coffee Volume I : Chemistry. Elsevier Applied. Science Publishers, London.

[6] Figaro. 2004, "General Information for TGS Sensor", figarosensor.com

[7] Rahayoe, Sri. dkk. 2007. Laporan Hasil Penenlitian Perancangan "Hidung Elektronik" Untuk Penentuan Kualitas Aroma Teh Dengan Menggunakan Sistem Jaringan Syaraf. FTP UGM, Yogyakarta.

[8] Siang, Jong Jek. 2004. Jaringan Syaraf tiruan \& Pemrogramannya Menggunakan MATLAB. Penerbit Andi, Yogyakarta.

\section{Biodata Penulis}

Derisma adalah seorang pengajar di Fakultas Teknologi Informasi Universitas Andalas sejak tahun 2010. Penulis menamatkan pendidikan S1 di Universitas Andalas pada tahun 2005 dan menamatkan pendidikan S2 di Institut Teknologi Bandung pada tahun 2010. 